\title{
Factors Affecting Target Leverage in Companies Listed in Indonesia Stock Exchange from 2014 to 2018
}

\author{
Nurul Kamila ${ }^{1}$, Imo Gandakusuma ${ }^{2}$ \\ \{kamila.n010@gmail.com $\left.{ }^{1}\right\}$ \\ Universitas Indonesia, Indonesia ${ }^{1,2}$
}

\begin{abstract}
This study aims to find out whether companies in Indonesia have the existence of target capital structure and factors that affect target leverage for the period 2014 to 2018. This study uses a dynamic partial adjustment model with a generalized method of moments estimator. The company's leverage target is influenced not only by companyspecific factors but also by corporate governance variables so that the corporate governance variable is included in this study. The results of this research indicate that companies in Indonesia appear to have target leverage and are reported to adjust their leverage towards the target level with the adjustment speed of Indonesian firms is 50,29\% thus it took 1,98846 years to reach the leverage target. Firm-specific factors such as profitability, size, growth, and tangibility have a significant effect, and corporate governance factors such as board size and family ownership have a significant effect on leverage. The sample of companies is only in Indonesia so that further research can be expanded by adding companies in other countries besides Indonesia and the addition of independent variables. This study of the listed firms in Indonesia contributes to the literature by examining the speed of adjustment and the determinants of optimal leverage.
\end{abstract}

Keywords: Leverage, Capital Structure Dynamics, Speed of Adjustment, Corporate Governance, Generalized Method of Moments.

\section{Introduction}

Successful selection and use of capital are some of the key elements of a company's financial strategy. Good or bad capital structure will have a direct effect on the financial position of the company, which then ultimately affects the value of the company. Based on trade-off theory capital structure can maximize the value of the company if the costs and benefits derived from additional debt reach balance. Referring to Elsas and Florysiak [1] in the theory of dynamic model structures, it predicted that corporate leverage would systematically deviate from the target even though it uses the trade-off theory capital structure. In an environment without friction, companies can efficiently adjust leverage to the target leverage. Still, because of asymmetric information, transaction costs, and other adjustment costs, companies cannot fully adjust their actual leverage from the previous period to the target leverage. After knowing that there is a position that is not optimal in the capital structure, the dynamic conditions can be seen by researching the direction of change and how quickly the company reaches its optimal capital structure or known as the speed of capital structure adjustment. The speed at which a company reaches target leverage is a speed of adjustment. The company will gradually make adjustments to the optimal capital structure. The speed of adjustment of optimal capital structure can be valuable information for investors to manage their portfolio. Companies that make adjustments quickly give a positive signal to investors 
where managers can make better decisions regarding capital structure and maximize corporate values [2].

This study provides an overview of capital structure in emerging economies. The characteristics of companies in developing and developed countries have differences mostly in the context of concentrated share ownership and control also generally family ownership or state ownership. Although many new instruments for financing such as perpetual bonds, green bonds, regional bonds, as well as several other alternatives through the capital market, conventional financing such as bank loans are still included in the list of instruments chosen by the issuer in 2018 (https://investasi.kontan.co.id), banks, as a primary financing alternative and high ownership concentration, make the speed of adjustment and optimal leverage substantial from a research perspective.

This study is focused on optimizing the capital structure by analyzing various variables that affect the capital structure of companies registered in Indonesia. In practice, real target leverage is something that cannot be observed so some literature studies try to solve these obstacles, namely for the proxy of the target leverage the observed leverage ratio is used. Corporate governance variables are included in this study because target corporate leverage is influenced, not only by firm-specific factors but also by governance variables [3]. The corporate governance system leads to a collection of regulations and encouragement used by management to direct and oversee the course of company activities. Therefore, good corporate governance can have a positive impact on the company. Based on this description, the author will research the factors that influence target leverage in companies listed on the Indonesia Stock Exchange. The research objectives are to find out whether companies in Indonesia have the existence of target capital structure and factors that affect target leverage for the period 2014 to 2018.

This research is expected to provide a reference to company managers in policy-making by taking into account factors of corporate characteristics, corporate governance practices, and adjustments to the capital structure of companies listed on the Indonesia Stock Exchange. The paper proceeds as follows. In section 2, a literature review related to this research is explored. Then, the methodology is presented in section 3. Results and Discussion are presented in section 4 . The final section 5 concludes the paper.

\section{Literature Review}

\subsection{Modigliani and Miller}

Modigliani and Miller [4] stated that the company's capital structure would not affect the value of the company. Based on the assumption of investor and capital market behavior that securities are traded on a perfect capital market, and all information for making decisions is relevant and available, or there is no information asymmetry. Also, there are no fees, such as transaction fees, bankruptcy fees, and taxes. From these assumptions, Modigliani and Miller's theory argues that the optimal debt to capital ratio does not exist, and shareholder wealth is not related to capital structure. In their seminal paper, Modigliani and Miller contend that the value of a levered firm is the same as the value of unlevered firms so that the capital structure does not need to be considered by managers and managers can freely determine the choice of capital structure composition. This theory, although theoretically solid, uses unrealistic assumptions, because the world without taxes is invalid [5]. 


\subsection{Trade-off theory}

Opinion from Modigliani Miller that corporate tax will increase the value of the company, so from the statement, the maximum debt selection must be chosen by all companies. But in the real world, the theory cannot predict corporate behavior. Therefore, other authors argue that reducing the value of the levered firm is related to bankruptcy and associated costs. The integration of tax effects and distress costs is shown in Figure 1. The value of companies in the world without bankruptcy costs is represented by a diagonal straight line. The curve of the curve is the value of the firm with these costs. When a company moves from all equity to a small amount of debt, the curve will rise, because the probability of distress is minimal, so the present value at the distress cost is minimum, the present value of these costs will increase at an increasing rate.

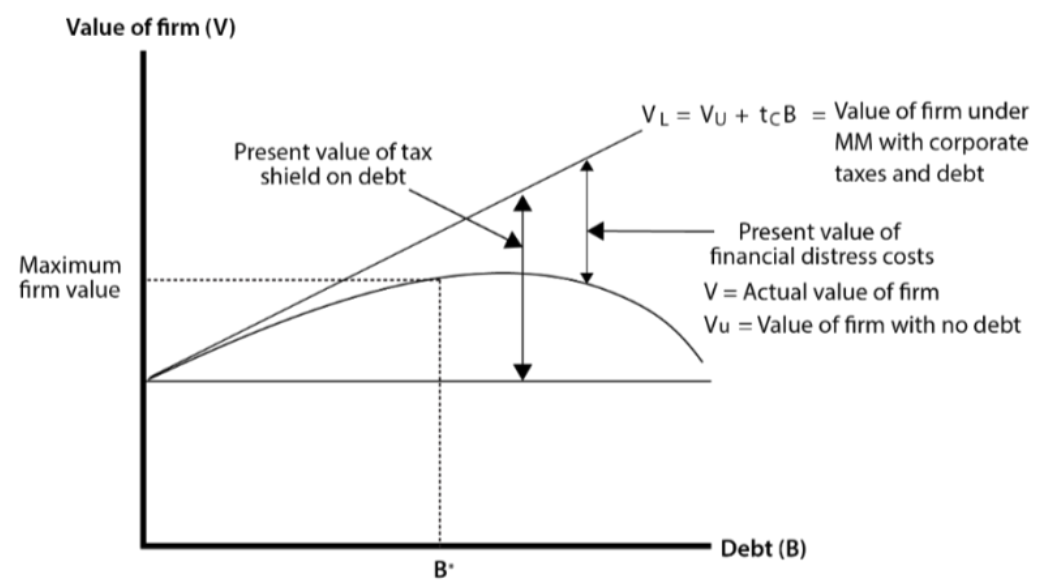

Fig. 1. The Optimal amount of Debt and the Value of the Firm [6].

An increase in the present value of these costs from additional debt dollars will equal an increase in the present value of the tax shield at some point. The point marked by $\mathrm{B}^{*}$ is the level of debt that maximizes the value of the company, which can be seen in Figure 1. Therefore $\mathrm{B}^{*}$ is the optimal amount of debt. The value of the company will decline due to an increase in bankruptcy costs that are faster than the tax shield beyond that point. It implies that the company will involve a trade-off between the tax benefit of debt and the cost of financial distress for capital structure decisions. So for each company, there will be an optimal amount of debt, and the amount of debt is the company's debt target. Bankruptcy costs increase faster than the tax shield beyond this point, implying a reduction in the value of the company from further leverage. It shows that the company's capital structure decision involves. The implication is that there is an optimal amount of debt for each company. This amount of debt is the target level of the company's debt [6].

\subsection{Dynamic Capital Structure Theory}

Dynamic Capital Structure Theory states that companies gradually make adjustments over time to their optimal capital structure. If the cost of adjustment is zero, the company will not be pushed to deviate from its optimal capital structure, and adjustments will be made immediately; however, due to market imperfections such as information asymmetry and 
funding costs, the company may deviate from its optimal capital structure. The cost of balancing leverage will affect the speed of adjustment of the company's capital structure. The actual and desired leverage ratios may not be the same at some time due to market disruptions. Market shifts, such as transaction costs, prevent a company from adjusting its actual capital structure to an optimal level immediately, which will ultimately affect the speed or slow process of capital structure adjustment [7].

\subsection{Corporate Governance}

According to the OECD Principles of Corporate Governance [8], Corporate governance involves a series of relationships between company management, the board of directors, shareholders, and other stakeholders. Corporate governance also provides a structure through which the company's goals are set, and the means to achieve those goals and monitor performance are determined. Corporate governance aims to help build the environment of trust, transparency, and accountability needed to foster long-term investment, financial stability, and business integrity to support stronger growth and a more inclusive society. The quality of corporate governance affects the costs for companies to access capital for growth and the trust that those who provide capital - directly or indirectly - can participate and share in their value creation on fair and equitable terms [8].

\subsection{Determinants of Leverage}

Buvanendra et al. [3] found that profitability variables have a negative and significant relationship in companies in Sri Lanka which indicates that profitable companies tend to reduce debt positions with retained-earning, growth opportunity variables have a positive relationship with companies in India which showed that to achieve high growth, companies in India carried out debt financing, a positive relationship to leverage shows that tangible assets in company ownership allow companies to take on more debt financing because they have collateral to secure credit and reduce the risk for lenders. For larger companies, it is usually easier to increase new debt or new equity because larger companies provide more information to the public, which results in low asymmetric information. The size of the company produces a positive and significant effect, as researched by Tamirat, Trujillo-Barrera, and Pennings [9]; Etudaiye-Muhtar and Ahmad [10] and Yang, Albaity, and Hassan [11]. There is another tax reduction, namely depreciation, so leverage is also affected by the non-debt tax shields, an increase from this which could potentially negatively affect leverage, in a study by Yang et al. [11] found a negative relationship to leverage, debt will be less attractive to companies that have high non-debt tax shields. Corporate governance factors are also considered in several studies such as board size, Ganiyu and Abiodun [12] found a positive relationship which showed that large boards tended to carry out effective monitoring because a large number of directors applied high debt levels to increase company value; Schmid [13] found that familycontrolled companies will use lower debt because they avoid the risk of default associated with the tendency that families use a longer perspective than companies that use operational managers and compensation can reduce agency problems which can then facilitate the timely convergence of target capital structures [3]. 


\section{Research Methods}

\subsection{Sources and Data Research}

Criteria for selecting the data in this study are Indonesian companies in sectors other than banking, finance, insurance, and utilities that are listed in the Indonesia Stock Exchange the period 2013-2018 due to the financial and business characteristics that are typical. Also, the company has complete data associated with variables research at Thomson Reuters Data Stream during the years 2013-2018.

\subsection{Research Variable}

The variables used in this study consisted of two types of a dependent variable and an independent variable.

\subsubsection{Dependent variables}

Leverage (LEV) is to calculate the company's capital structure. Researchers use the bookdebt ratio because it is not distorted by a market expectation of uncertainty and instability from time to time [3].

Leverage $_{i t}=\frac{\text { Total debtit }_{\text {it }}}{\text { Total assetsit }}$

\subsubsection{Independent Variables}

Independent variables used in this study to explain the variation in the target leverage ratio consists of the variable characteristics of the company and corporate governance.

(1) Lag leverage

Leverage $_{i t-1}=\frac{\text { Total debt }_{i t-1}}{\text { Total assetsit-1 }}$

(2) Profitability

Profitabiit $_{\text {it }}=\frac{\text { EBIT }_{\text {it }}}{\text { Total Assets }_{\text {it }}}$

(3) Size

Size $_{i t}=$ Natural logaritm of total assets it $_{\text {it }}$

(4) Growth Opportunity

Growt $_{i t}=\frac{\text { Market }_{\text {capitalisation }} \text { it }}{\text { Common equity }_{\text {it }}}$

(5) Non-debt tax shield

Non - debt tax shield it $=\frac{\text { Depreciation }_{\text {it }}}{\text { Total assets }_{\text {it }}}$ 
(6) Tangibility

Tangibility $_{\text {it }}=\frac{\text { Tangible fixed assetsit }}{\text { Total assetsit }}$

(7) Board Size

Total the number of directors on the board of a company.

(8) Family ownership (Dummy)

Using a dummy variable that is one, if a family or a family member is the controlling shareholder; otherwise, set to zero.

(9) Percent of directors' compensation

Percent of directors' compensation $_{i t}=\frac{\text { Remuneration of directors }_{i t}}{\text { Staff } \operatorname{cost}_{i t}}$

\subsection{Research Model}

The target leverage ratio for firm $\mathrm{i}$ in period $\mathrm{t}$ is set as $\mathrm{LEV} * \mathrm{it}$. Then Xit represented as a set of independent variables, which have been used as a previous study by Buvanendra et al. [3] and Etudaiye-Muhtar and Ahmad [10]. The model used is as follows:

$L E V^{*}{ }_{i t}=\beta X_{i t}+\varepsilon_{i t}$

Market without friction, an observed leverage ratio of firm $\mathrm{i}$ at time $\mathrm{t}$, denoted as $\mathrm{Lev}_{\text {it }}$ must equal the target leverage ratio, i.e., $\mathrm{Lev}_{\mathrm{it}}=\mathrm{Lev}^{*}{ }_{\mathrm{it}}$. In a perfect environment, the difference between the observed capital structure in the current period and the previous period will be the same as the difference between the target capital structure and the capital structure of the previous period. But in the practical world, due to market imperfections that cause the costs of adjustment, the company may not fully adjust their actual debt ratio from the previous period to the current target debt ratio. Therefore, the partial adjustment, the company's leverage ratio was observed at any point in time generally will not be the same as the target leverage ratio. A model of partial adjustment may represent the following as in equation (1):

$$
L E V_{i t}-L E V_{i t-1}=\lambda\left(L E V^{*}{ }_{i t}-L E V_{i t-1}\right)
$$

Where $\operatorname{Lev}_{\text {it }}$ and $\operatorname{Lev}_{\text {it- } 1}$ is leverage for firm $\mathrm{i}$ in period $\mathrm{t}$ and $\mathrm{t}-1$ and $\lambda$ represents the speed of adjustment. If the rate adjustment lags slow or fast, the leverage will be close to zero, and if the level of adjustment of the company is fast or high, then the lag leverage has a value close to one.

By combining or substituting equations (1) and (2), it can be derived as follows:

$$
\begin{aligned}
& L E V_{i t}=L E V_{i t-1}+\lambda\left(L E V_{i t}^{8}-L E V_{i t-1}\right) \\
& L E V_{i t}=L E V_{i t-1}+\lambda L E V_{i t}^{8}-\lambda L E V_{i t-1} \\
& L E V_{i t}=(1-\lambda) L E V_{i t-1}+\lambda \beta X_{i t}+\varepsilon_{i t}
\end{aligned}
$$

The research model used by equation (5) can be described as follows:

$$
\begin{gathered}
L E V_{i t}=(1-\lambda) L E V_{i t-1}+\lambda \beta_{1} P R O F_{i t}+\lambda \beta_{2} S Z_{i t}+\lambda \beta_{3} G R O W_{i t}+\lambda \beta_{4} T A N G_{i t}+\lambda \beta_{5} N D T S_{i t} \\
+\lambda \beta_{6} \text { Bsize }_{i t}+\lambda \beta_{7} F O_{i t}+\lambda \beta_{8} P D C_{i t}+\varepsilon_{i t}
\end{gathered}
$$




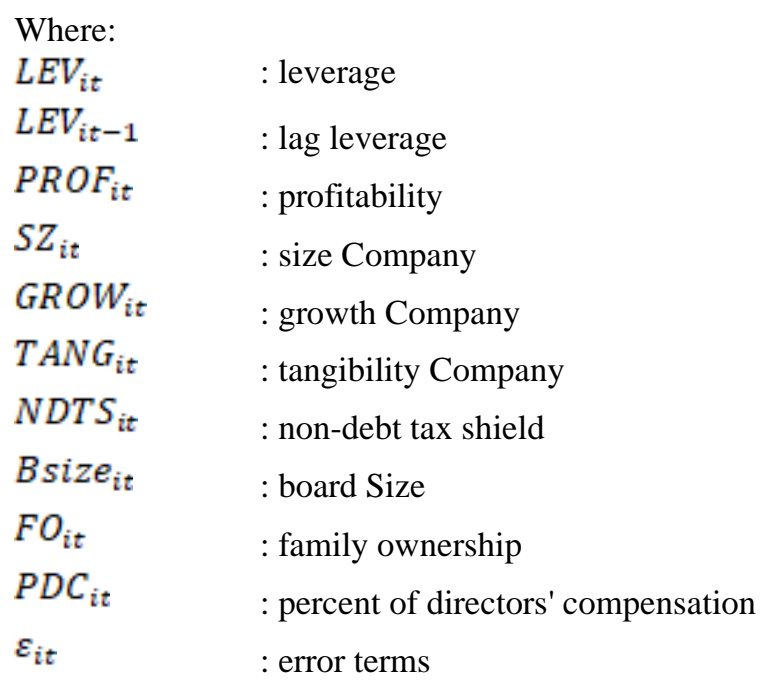

\subsection{Data Analysis Method}

The data used to support the goals of this research is that panel data that non-financial companies listed on the Indonesia Stock Exchange 5 years (2014-2018). The combination of time series data and cross-section is panel data. Time series is data in a certain time frame collected from an individual, while the cross-section is data within a specific time that is collected by many individuals. if the model is estimated with a fixed effect or random effect approach it will produce biased and inconsistent estimation results due to the presence of lag dependent variables that can cause endogeneity problem [14]. In addressing this problem, Arellano and Bond using the method of moments approach or called the generalized method of moments (GMM), which is known to overcome the issues of endogeneity resulting from the use of the dependent variable lag. Wald test, Sargan test and Arellano-Bond test (AR2) will be carried out to test the feasibility of the model using the GMM estimation method.

\section{Results and Discussion}

Generalized Method of Moment (GMM) estimation is used to determine the effect of firm-specific factors and corporate governance factors on the leverage so that in table 1 the estimated results of the research model are presented. After estimation is done, the next is to test the validity of the model used. Tests used are the Wald test, AR(2) test, and Sargan Test. From the Wald test was found that as a whole, the independent variables significantly influence the dependent variable. The $\operatorname{AR}(2)$ test shows that there is no second-order autocorrelation in the research model, while the sargan test indicates that the instruments used in the research model are valid and are not over-identified. 


\subsection{The presence of target leverage and speed of adjustment}

Table 1 presents the results of the estimation of the factors that affect the target leverage on companies in Indonesia. In the lagged variable leverage shows a significant coefficient thus supporting dynamic trade-off theory. The leverage target is having a coefficient value of 0.497100 , so the speed of adjustment is estimated at 50.29\% (1-0.497100), which indicates that the company is adjusting the current leverage level to the target value at the level of $50.29 \%$ per year, implying every year the company reaching around $50.29 \%$ of the target leverage. It takes 1,98846 years $(1 / 0.5029)$ years to reach the target so that it can be concluded that the company closed the gap between current leverage and the target in almost two years.

Table 1. Regression Results

\begin{tabular}{|c|c|c|}
\hline \multicolumn{3}{|c|}{ Dependent Variable: Leverage (LEV) } \\
\hline Variable & Coef. & Prob. \\
\hline $\operatorname{LEV}(-1)$ & 0.497100 & $0.0009 * *$ \\
\hline Profitability & -0.333113 & $0.0000 * * *$ \\
\hline Size & 0.061770 & $0.0205 * *$ \\
\hline Growth & 0.004603 & $0.0519 *$ \\
\hline Tangibility & 0.095963 & $0.0133 * *$ \\
\hline Non-debt tax shield & -0.794201 & 0.3662 \\
\hline Board Size & 0.005835 & $0.0501 *$ \\
\hline Family Ownership & -0.045756 & $0.0011 * *$ \\
\hline \% Directors' compensation & -0.033752 & 0.7729 \\
\hline Number of observations & & \\
\hline Wald test & & \\
\hline $\mathrm{AR}(2)$ test & & \\
\hline Sargan test & & \\
\hline
\end{tabular}

Significant at $10 \%$ alpha value is marked by *

Significant at $5 \%$ alpha value is marked by $* *$

Significant at $1 \%$ alpha value is marked by $* * *$

Source: Data Collected and Processed by the Author.

\subsection{Determinants of Leverage}

Six variables were found to be significant in influencing the target leverage of companies in Indonesia during the period under study. These variables are profitability, size, growth opportunity, tangibility, board size, and family ownership. Profitability negatively affects leverage in the sample company, the higher the profitability, the lower the leverage, thus supporting the pecking order theory. It shows that companies with high profits in their capital structure will use less debt financing, which indicates that profitable companies will use the retention of profits to reduce debt positions. A profitable company can be said to have good internal finance because the company tends to have high retained earnings. This finding is consistent with Buvanendra et al. [3], Tamirat et al. [9] and Oino and Ukaegbu [15].

Size influences leverage positively on the companies sampled, which indicates that the company that is more diversified is the larger company. Hence, companies can use higher leverage because they have more capacity to use leverage. A positive relationship between size and leverage supports the trade-off theory. For asymmetric information, for large companies, the level of information asymmetry in the market will be much lower, as more 
information is expected to be available to large companies. These large companies can turn to debt financing, so there is a positive relationship. With a much lower level of asymmetric information, it is more likely for these large companies to turn to debt financing, hence a positive relationship. This finding is consistent with Etudaiye-Muhtar and Ahmad [10], Oino and Ukaegbu [15], Tamirat et al. [9] and Nehrebecka and Dzik-Walczak [16].

Growth Opportunity affects leverage positively on the companies that are sampled, the higher the growth, the higher the leverage. It shows that companies will use debt financing to achieve higher growth [3]. When a company has a growth opportunity, there will be a possibility that the company will carry out debt financing, especially if the company does not have sufficient retained earnings. The use of debt will give a good signal to the market, indicating that more debt shows the company is confident of the prospect of his company [9]. This finding is consistent with Buvanendra et al. [3], Tamirat et al. [9], and Oino and Ukaegbu [15].

Tangibility influences leverage positively on the companies sampled. The higher the tangibility, the higher the leverage, there is a positive correlation following the trade-off theory which states that companies with higher tangible assets will have the ability to finance the debttim, because it will have a higher credit rating if it has higher tangible assets. This finding is consistent with research conducted by Buvanendra et al. [3].

For corporate governance variables, only board size and family ownership produce significant probabilities, while for percent of directors' compensation variables are not significant. Board size positively affects the leverage of the company being sampled, the higher the board size, the higher the leverage. Large board members can improve the company by using external funds. This finding is consistent with research conducted by Jaradat [17]. Also, large boards tend to carry out effective monitoring with the aim of increasing the value of the company thus applying a high level of debt due to an adequate number of board sizes, and take the opportunity to be able to carry out expansion activities [12].

Family ownership negatively affects leverage in companies that are sampled, which indicates that research shows that family-controlled companies will use lower debt compared to companies controlled by professional managers [18]. Family ownership can be more sensitive about using leverage, which is associated with a tendency for companies with family ownership to use a longer perspective than managers [19]. This finding is consistent with Schmid [13], which states that to avoid the risk of default, the relationship between family ownership and leverage is negative.

\section{Conclusions}

This research was conducted to determine the dynamic aspects of the capital structure, such as the existence of target leverage, speed of adjustment, and the factors that influence leverage in companies in Indonesia. This study covers a period of 5 years, namely 2014 to 2018. By using the GMM estimator, it was found that Indonesian companies practice target leverage and leverage influenced by firm-specific factors such as profitability, size, growth opportunity, and tangibility, while corporate governance factors are board-size and family ownership. Profitability has a negative effect on leverage, while size, growth opportunity, and tangibility have a positive effect on leverage. On corporate governance factors, board size has a positive effect on leverage, while family ownership has a negative effect on leverage. This research contributes to the empirical literature by analyzing the determinants of target leverage 
in Indonesian companies. The limitations of study in this research are related to research data because some of the research data needed in this study are not available on the Thomson Reuters Data stream and company annual reports so that the number of sample companies used in this research is 155 companies. In this study, the sample of companies is only in Indonesia so that further research can be expanded by adding companies in other countries besides Indonesia and the addition of independent variables or exploring new firm specific factors and corporate governance. For managerial implications, companies in Indonesia must be careful of bankruptcy costs that can arise from the use of excessive debt if it optimizes the tax benefits obtained from the use of debt, so company managers must estimate the target capital structure that can be used as a guide in conducting policies on corporate financing. Company managers can use the influence of corporate characteristics and corporate governance as well as the speed of capital structure adjustment so that companies can optimize the cost of capital and ultimately achieve good corporate value. Regulators are expected to consider the results of this research in making regulations for companies in Indonesia related to leverage and also adjustment costs that can help develop companies in Indonesia.

\section{References}

[1] R. Elsas and D. Florysiak, "Dynamic Capital Structure Adjustment and the Impact of Fractional Dependent Variables," J. Financ. Quant. Anal., vol. 50, no. 5, pp. 1105-1133, 2015.

[2] B. Supra, V. Narender, N. Jadiyappa, and G. Girish, "Speed of adjustment of capital structure in emerging markets," 2016.

[3] S. Buvanendra, P. Sridharan, and S. Thiyagarajan, "Firm characteristics, corporate governance and capital structure adjustments: A comparative study of listed firms in Sri Lanka and India," IIMB Manag. Rev., vol. 29, no. 4, pp. 245-258, 2017.

[4] F. Modigliani and M. H. Miller, "The cost of capital, corporation finance and the theory of investment," Am. Econ. Rev., vol. 48, no. 3, pp. 261-297, 1958.

[5] D. Yapa Abeywardhana, "Capital structure theory: An overview," Account. Financ. Res., vol. 6, no. $1,2017$.

[6] S. A. Ross, R. Westerfield, and J. Jaffe, Corporate finance 11th Edn. Dubuque: Published by McGraw-Hill Education, 2016.

[7] E. O. Fischer, R. Heinkel, and J. Zechner, "Dynamic capital structure choice: Theory and tests," J. Finance, vol. 44, no. 1, pp. 19-40, 1989.

[8] G20/OECD, “G20/OECD principles of corporate governance," 2015.

[9] A. Tamirat, A. Trujillo-Barrera, and J. M. Pennings, "Target Capital Structure: Dynamics, Determinants and Speed of Adjustment."

[10] O. F. Etudaiye-Muhtar and R. Ahmad, "Empirical evidence of target leverage, adjustment costs and adjustment speed of non-financial firms in selected African countries," Int. J. Econ. Financ. Issues, vol. 5, no. 2, pp. 482-488, 2015.

[11] Y. Yang, M. Albaity, and C. H. B. Hassan, "Dynamic capital structure in China: determinants and adjustment speed," Invest. Manag. Financ. Innov., vol. 12, no. 2, pp. 195-204, 2015.

[12] Y. O. Ganiyu and B. Y. Abiodun, "The impact of corporate governance on capital structure decision of Nigerian firms," Res. J. Organ. Psychol. Educ. Stud., vol. 1, no. 2, pp. 121-128, 2012.

[13] T. Schmid, "Control considerations, creditor monitoring, and the capital structure of family firms," J. Bank. Financ., vol. 37, no. 2, pp. 257-272, 2013.

[14] M. Verbeek, A guide to modern econometrics. Hoboken, N.J.: Wiley custom, 2017.

[15] I. Oino and B. Ukaegbu, "The impact of profitability on capital structure and speed of adjustment: An empirical examination of selected firms in Nigerian Stock Exchange," Res. Int. Bus. Financ., vol. 35, pp. 111-121, 2015.

[16] N. Nehrebecka and A. Dzik-Walczak, "The dynamic model of partial adjustment of the capital 
structure. Meta-analysis and a case of Polish enterprises," Zb. Rad. Ekon. Fak. u Rijeci časopis za Ekon. Teor. i praksu, vol. 36, no. 1, pp. 55-81, 2018.

[17] M. S. Jaradat, "Corporate governance practices and capital structure: A study with special reference to board size, board gender, outside director, and CEO duality," Int. J. Econ. Commer. Manag., vol. 3, no. 5, pp. 264-273, 2015.

[18] D. L. McConaughy, M. C. Walker, G. V. Henderson Jr, and C. S. Mishra, "Founding family controlled firms: Efficiency and value," Rev. Financ. Econ., vol. 7, no. 1, pp. 1-19, 1998.

[19] Sugiarto, Struktur modal, struktur kepemilikan perusahaan, permasalahan keagenan \& informasi asimetri. Yogyakarta: Graha Ilmu, 2009. 